American University Washington College of Law

Digital Commons @ American University Washington College of Law

2-25-2021

\title{
The Way to Barbara Armstrong, First Tenure-Track Law Professor in an Accredited US Law School
}

Susan Carle

American University Washington College of Law, scarle@wcl.american.edu

Follow this and additional works at: https://digitalcommons.wcl.american.edu/facsch_bk_contributions

Part of the Law and Gender Commons, Legal Education Commons, and the Legal Profession Commons

\section{Recommended Citation}

Carle, Susan, "The Way to Barbara Armstrong, First Tenure-Track Law Professor in an Accredited US Law School" (2021). Contributions to Books. 305.

https://digitalcommons.wcl.american.edu/facsch_bk_contributions/305

This Book Chapter is brought to you for free and open access by the Scholarship \& Research at Digital Commons @ American University Washington College of Law. It has been accepted for inclusion in Contributions to Books by an authorized administrator of Digital Commons @ American University Washington College of Law. For more information, please contact kclay@wcl.american.edu. 
GENDER AND CAREERS IN THE LEGAL ACADEMY 
Oñati International Series in Law and Society

\section{A SERIES PUBLISHED FOR THE OÑATI INSTITUTE FOR THE SOCIOLOGY OF LAW}

General Editors

$$
\text { Rosemary Hunter David Nelken }
$$

Founding Editors

William L F Felstiner Eve Darian-Smith

Board of General Editors

Carlos Lugo, Hostos Law School, Puerto Rico

Jacek Kurczewski, Warsaw University, Poland

Marie-Claire Foblets, Leuven University, Belgium

Ulrike Schultz, Fern Universität, Germany

Recent titles in this series

Transitional Justice and the Public Sphere: Engagement, Legitimacy and Contestation

Edited by Chrisje Brants and Susanne Karstedt

Law and the Precarious Home: Socio Legal Perspectives on the Home in Insecure Times

Edited by Helen Carr, Brendan Edgeworth and Caroline Hunter

Criminologies of the Military: Militarism, National Security and Justice

Edited by Andrew Goldsmith and Ben Wadham

Law and the Precarious Home: Socio Legal Perspectives on the Home in Insecure Times

Edited by Helen Carr, Brendan Edgeworth and Caroline Hunter

Collective Bargaining and Collective Action: Labour Agency and Governance in the 21st Century?

Edited by Julia López López

Fundamental Rights and Legal Consequences of Criminal Conviction

Edited Sonja Meijer, Harry Annison and Ailbhe O'Loughlin

Digital Family Justice: rom Alternative Dispute Resolution to Online Dispute Resolution?

Edited by Mavis Maclean and Bregje Dijksterhuis

The Legacies of Institutionalisation: Disability, Law and Policy in the 'Deinstitutionalised' Community

Edited by Claire Spivakovsky, Linda Steele and Penelope Weller

Gender and Careers in the Legal Academy

Edited by Ulrike Schultz, Gisela Shaw, Margaret Thornton and Rosemary Auchmuty

For the complete list of titles in this series, see

'Oñati International Series in Law and Society' link at

www.bloomsburyprofessional.com/uk/series/

onati-international-series-in-law-and-society 


\title{
Gender and Careers in the Legal Academy
}

\author{
Edited by \\ Ulrike Schultz \\ Gisela Shaw \\ Margaret Thornton \\ and \\ Rosemary Auchmuty \\ Oñati International Series in Law and Society \\ A SERIES PUBLISHED FOR THE OÑATI INSTITUTE \\ FOR THE SOCIOLOGY OF LAW
}


HART PUBLISHING

Bloomsbury Publishing Plc

Kemp House, Chawley Park, Cumnor Hill, Oxford, OX2 9PH, UK

1385 Broadway, New York, NY 10018, USA

HART PUBLISHING, the Hart/Stag logo, BLOOMSBURY and the Diana logo are trademarks of Bloomsbury Publishing PIC

First published in Great Britain 2021

Copyright (C) The editors and contributors severally 2021

The editors and contributors have asserted their right under the Copyright, Designs and

Patents Act 1988 to be identified as Authors of this work.

All rights reserved. No part of this publication may be reproduced or transmitted in any form or by any means, electronic or mechanical, including photocopying, recording, or any information storage

or retrieval system, without prior permission in writing from the publishers.

While every care has been taken to ensure the accuracy of this work, no responsibility for loss or damage occasioned to any person acting or refraining from action as a result of any statement in it can be accepted by the authors, editors or publishers.

All UK Government legislation and other public sector information used in the work is Crown Copyright $\odot$. All House of Lords and House of Commons information used in the work is Parliamentary Copyright ( $\odot$. This information is reused under the terms of the Open Government Licence v3.0 (http://www.nationalarchives.gov.uk/doc/ open-government-licence/version/3) except where otherwise stated.

All Eur-lex material used in the work is @ European Union, http://eur-lex.europa.eu/, 1998-2021.

A catalogue record for this book is available from the British Library.

Library of Congress Cataloging-in-Publication data

ISBN: HB: 978-1-50992-311-3

ePDF: $\quad 978-1-50992-313-7$

ePub: $\quad 978-1-50992-312-0$

Typeset by Compuscript Ltd, Shannon

Printed and bound in Great Britain by CPI Group (UK) Ltd, Croydon CR0 4YY

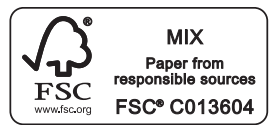

To find out more about our authors and books visit www.hartpublishing.co.uk. Here you will find extracts, author information, details of forthcoming events and the option to sign up for our newsletters. 


\section{Preface}

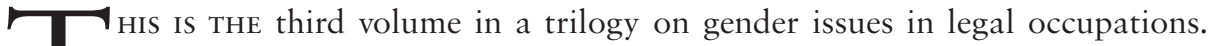
An overview of Women in the World's Legal Professions (Schultz and Shaw 2003) was followed by Gender and Judging (Schultz and Shaw 2013), finally to be completed by this study on women teachers of law. All three books have been published by Hart Publishing, to whom we are grateful for their unceasing support over so many years. Our thanks also go to the International Institute for the Sociology of Law for facilitating the inclusion of all three volumes in their Oñati Socio-Legal Series.

The project has stretched over decades. In the 1980s, as contributor to the Abel and Lewis project on Lawyers in Society, I took the decision to focus my work on Women/Gender in the Legal Profession, at the time a marginal subject. This then became a lifetime preoccupation, complementing related concerns such as the legal profession, gender and law, and legal education.

In 1994 a group of women, amongst them the four editors of this book, founded a gender issues sub-section of the Legal Profession Group, ${ }^{1}$ a working group of the Research Committee for the Sociology of Law. Now all aged 70-plus, we are closely familiar with the difficulties and injustices facing early women academics. As members of this pioneering generation, we are attempting to come to terms with our own past, itself part of women's legal history. By capturing developments in different countries, tracing similarities and differences, and identifying lasting structural problems and ongoing deficits, we hope to help prepare the ground for full gender justice in the academy.

The topic of women law professors has been on my mind for a long time. Celia Wells, herself one of the early (and very few) female law professors in the UK, inspired me with her contribution to the first book of our series, entitled 'The Remains of the Day: The Women Law Professors Project', ${ }^{2}$ a blend of personal memories and an empirical study of her colleagues' life realities. For this volume she has written an autobiographical report, while editing her memoirs A Woman in Law: Reflections on Gender, Class and Politics. ${ }^{3}$ Other sources of inspiration have been Fiona Cownie's book Legal Academics: Culture and Identities' and the chapter on 'Women in the Legal Academy' in Margaret Thornton's Dissonance and Distrust: Women in the Legal Profession. ${ }^{5}$

\footnotetext{
${ }^{1}$ See: rcsl.iscte.pt/rcsl_wg_professions.htm.

${ }^{2}$ See 'Working Out Women in Law Schools' (2001) 21 Legal Studies 116; 'Women Law Professors Negotiating and Transcending Gender Identities at Work' (2002) 10 Feminist Legal Studies 1.

${ }^{3}$ Hook, Hampshire, Waterside Press, 2019.

${ }^{4}$ Oxford, Hart Publishing, 2004.

${ }^{5}$ Melbourne, Oxford University Press, 1996.
} 
My work was made possible by a German governmental grant in 2011 for a project called 'JurPro', an empirical study of gender and academic legal careers in Germany (funding line 'Women to the Top'). ${ }^{6}$ I immediately invited colleagues to join me in a comparative project. Some were already working on aspects of this subject, some were encouraged to embark on data collections and interviews, and some enjoyed the opportunity to write biographical reports on early women law professors. As it turned out, the topic attracted a good deal of interest.

There is now an extended network of colleagues working on gender issues in the legal professions and on gender and law generally. In addition, over the past 20 years the number of women teaching law or working in sociology of law and the sociology of the professions has risen considerably - yet another indicator of change in this field. Thanks to improved technology, communication with colleagues in Africa and East Asia has been greatly facilitated. However, while the topic of women in the judiciary has remained on colleagues' research agenda, their focus on women in the academy has been much less pronounced.

I gave the first presentation on the subject at the big international socio-legal meeting in Honolulu, Hawaii, in 2012. Since then it has featured at annual meetings of the Research Committee for the Sociology of Law, annual meetings of the American Law and Society Association, and the biannual meetings of the Legal Profession Group. ${ }^{7}$ In 2012 I attended a workshop on Women Judges in Muslim Courts of Law, a welcome opportunity to recruit collaborators working on Arab countries. For the international socio-legal meeting in Mexico City in 2017 the project was given the status of an International Research Collaborative (IRC), which helped us to get travel funding for some colleagues from the American Science Foundation.

In May 2016 I arranged a meeting in the Schönburg, a twelfth-century castle in the historic city of Oberwesel in the mid-Rhine valley, a world heritage site opposite the famous Loreley rock. This became the starting point for our collective work on this volume. ${ }^{8}$ Twenty-five of the 35 contributors - five of them men - attended. Ultimately we collected 28 chapters representing 19 countries: UK (six), Australia (three), USA (two), Canada (two) and one each from the Philippines, India, China, Argentina, Brazil, Ghana, Israel, Kuwait, Egypt, Germany, the Netherlands, Belgium, Finland, Estonia and the Czech Republic. Nine of the countries were new to our overall project. Ten authors had already contributed to one or even two (Mary Jane Mossman and Hilary Sommerlad) of the preceding volumes.

${ }^{6} \mathrm{U}$ Schultz, A Böning, I Peppmeier and S Schröder, De jure und de facto: Professorinnen in der Rechtswissenschaft. Geschlecht und Wissenschaftskarriere im Recht (Baden-Baden, Nomos, 2018).

${ }^{7}$ Legal Profession Group Meeting Königswinter/Bonn 2012; LSA Boston 2013; RCSL Toulouse 2013; RCSL Onati 2014; Legal Profession Group Meeting Frauenchiemsee 2014; RCSL Canoas Brazil 2015; Legal Profession Group Meeting Andorra 2016; Mexico City 2017; Legal Profession Group Meeting Andorra 2018; RCSL Onati 2019.

${ }^{8}$ See: www.fernuni-hagen.de/jurpro/tagungen.shtml. This website shows the programme as well as video recordings of most of the presentations and it sets a link to further presentations on gender and careers in the legal academy from the Legal Profession Group Meeting in Bonn/Königswinter in July 2012 as well as presentations from the two JurPro conferences in Hagen including presentations in English by Margaret Thornton and Richard Collier. Presentations of the Legal Profession Group Meeting in July 2014 in Frauenchiemsee are shown here: www.fernuni-hagen.de/rechtundgender/vortraege.shtml. 
The project, drawing on long-standing collaboration and friendships, is once again truly interdisciplinary. Amongst the authors are lawyers, sociologists, historians, anthropologists, cultural scientists, philosophers, a political scientist, a Germanist and an Arabist, most of them scholars, some involved in equal opportunities practice at their universities, some also in practice as lawyers and (in one case) a judge.

This collective piece of work brings together not only different cultures and identities but also different generations of women, the youngest being in her late twenties and the oldest having passed the 80-year threshold. All ranks of the academic hierarchy are represented, resulting in a rich tapestry of differing perspectives and experiences.

One inevitable hurdle has proved to be language, since only half of the contributors are native speakers of English. This helps to explain not only the slight overrepresentation of Anglo-American perspectives but also the occasional idiosyncratic use of the English language by those valiantly struggling with the foreign idiom. Even the title of the book is the outcome of long discussions. Should it be gender in 'academia', 'the academe' or 'the academy'? Perhaps for reasons of rhythm I had initially chosen 'academy' and we stayed with this, as even language experts failed to reach agreement amongst themselves.

I have to thank my co-editors Gisela Shaw, Margaret Thornton and Rosemary Auchmuty, who have accompanied me with great patience through the long and often intense process of creating this work. Warmest thanks also go to my family, who not only put up with my occasional mental (and physical) absence but even supported my project throughout. My husband Christian was once again in charge of the partner programme in Schönburg, my daughter Ina helped with the administration of the meetings in Königswinter and Frauenchiemsee, and my granddaughter Lillan was involved in organisational issues of this volume.

Ulrike Schultz 


\section{Table of Contents}

Preface $v$

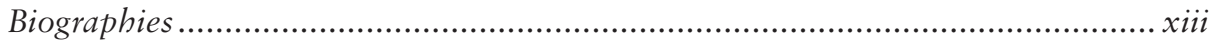

Introduction: Gender and Careers in the Legal Academy: Overview and Synthesis .......1 Ulrike Schultz

PART I

GENDER AND CAREERS IN THE LEGAL ACADEMY

1. Gender and Careers in the Legal Academy in Germany: Women's Difficult Path from Pioneers to a (Still Contested) Minority... 39 Ulrike Schultz

2. Gender and the Legal Academy in the UK: A Product of Proxies and Hiring and Promotion Practices...

Liz Duff and Lisa Webley

3. The Feminisation of Legal Academia in Quebec: Achievements and Challenges .79 Julie Paquin

4. Women, Difference and Identities in the Brazilian Legal Professoriate..... .95 Maria da Gloria Bonelli

5. India's Women Legal Academics: Who they are and Where You Might Find them.

Swethaa S Ballakrishnen and Rupali Samuel

6. Women in the Legal Academy at the Law School of the University of Buenos Aires

Beatriz Kohen, Sonia Ariza Navarrete and Maria de los Angeles Ramallo

7. Breaking the Veil of Masculinity? Women and the Legal Academy in Ghana

J Jarpa Dawuni

\section{PART II \\ HISTORY OF WOMEN IN LAW FACULTIES}

8. Why not Faster? Women in the Czech and Czechoslovak Legal Academy..... .173 Jan Kober 


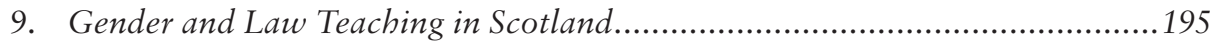
Peter Robson

10. Women's Entry and Integration into Israel's Legal Academia: History, Story, Non-Story and the Men(tor).... Eyal Katvan and Ruth Halperin-Kaddari

11. Women Legal Academics in China Xiaonan Liu

12. Women Law Teachers in the Philippines then, Now and Six Decades in between: The Cheerless Transformation of a Road Less Travelled to a Path Oft-Chosen for Convenience. 249 Emily Sanchez Salcedo

\section{PART III \\ FIRST AND EARLY WOMEN LAW PROFESSORS}

13. Madeleine Gevers-Dwelshauvers (1897-1994). A Grande Dame at the Université Libre de Bruxelles.... 269 Hans den Tonkelaar

14. Compromise, Autonomy and Courage: Derkje Hazewinkel-Suringa, First Female Law Professor in the Netherlands (1889-1970)

Leny de Groot-van Leeuwen

15. Inkeri Anttila, the First Woman Law Professor in Finland (1916-2013).... Harriet Silius

16. Women and the Legal Academy in Estonia: In Memory of Vera Poska-Grünthal, the First Woman Law Lecturer in Tartu

Merike Ristikivi

17. Alice Erh-Soon Tay and the Character of Legal Knowledge Susan Bartie

18. Oral History and Australia's First Women Law Professors

Kim Rubenstein

19. The Way to Barbara Armstrong, First Tenure-Track Law Professor in an Accredited US Law School. 355 Susan D Carle

20. Why Aisha Rateb could not become Egypt's First Female Judge, and became Egypt's First Female Law Professor Instead

Omnia Mehanna and Nadia Sonneveld

21. First Female Law Student and Law Professor in Kuwait: Badria Al-Awadhi Opens Doors for Women in Law 1967-2020 389

Rania Maktabi 


\section{PART IV \\ PERSONAL NARRATIVES}

22. Memories: Becoming a Law Professor 409

Celia Wells

23. 'Herculean Obstacles and Intrepid Complainants': The Sex Discrimination

Complaint at Osgoode Hall Law School, 1987-1994.

Mary Jane Mossman

PART V

FEMINISM IN THE LEGAL ACADEMY

24. The Road to Olive Stone 441

Rosemary Auchmuty and Jennifer Temkin

25. The First and Last(?) Feminist Law Professors in Australia 457 Margaret Thornton

26. Feminist Legal Academics: Changing the Epistemology of American Law through Conflicts, Controversies and Comparisons 475

Carrie Menkel-Meadow

\section{PART VI \\ REFLECTIONS ON MASCULINITIES AND FEMININITIES \\ IN THE LEGAL ACADEMY}

27. Rethinking Masculinities in the Legal Academy: Men, Gender and Legal Careers (Or, Whatever Happened to the 'Nutty Professor'?)

Richard Collier

28. Patriarchal Discourses in the UK Legal Academy: The Case of the Reasonable Man

Hilary Sommerlad

Index 549 


\section{Biographies}

Rosemary Auchmuty is Professor of Law at the University of Reading, UK. She writes about gender and sexuality in property law, marriage, children's books and legal history. She coordinated, with Erika Rackley, the Women's Legal Landmarks project (Rackley and Auchmuty (eds), Women's Legal Landmarks, Hart Publishing 2019) and has written articles on and about feminist legal history and feminist legal biography: r.auchmuty@reading.ac.uk.

Swethaa S Ballakrishnen is Assistant Professor of Law and Sociology at the University of California, Irvine and Affiliated Faculty at the Center of the Legal Profession, Harvard Law School. Their research examines relationships between gender, globalisation and law, especially within the contexts of higher education and professional work and has appeared in, among other journals, Law and Society Review, Law and Social Inquiry, Journal of Professions and Organization and the International Journal of the Legal Profession. A book on women lawyers in India is forthcoming with Princeton University Press (2020): sballakrishnen@law.uci.edu.

Susan Bartie is a Lecturer in Law at the University of Tasmania and the Coordinator of the Law School's Bachelor of Legal Studies degree. She is the author of several articles on the history of legal education and the role of lawyers in society. Her book, Free Hands and Minds - Pioneering Australian Legal Scholars, reveals some of the central and distinctive ideas that underpinned the birth of modern Australian university legal education: Susan.Bartie@utas.edu.au.

Maria da Gloria Bonelli is Senior Professor of Sociology at the Federal University of São Carlos, Brazil. She specialises in the sociology of professions and has published articles and books on this subject. Her current research focuses on the global and local dimensions of contemporary professionalisation and gender and difference in the legal professions in Brazil: gbonelli@uol.com.br.

Susan D Carle is Vice-Dean and Professor of Law at American University Washington College of Law in Washington, DC. She specialises in US civil rights history, employment and labour law, and legal ethics/professional responsibility. One of her recent works is Defining the Struggle: Organizing for Racial Justice, 1880-1915 (Oxford University Press, 2013, 2016): scarle@wcl.american.edu.

Richard Collier FAcSS FRSA is a Professor of Law at Newcastle University, UK. He has published widely in the area of law and gender and previous books have addressed masculinities, law and legal systems, family law, fatherhood, criminology, the legal profession and legal education and research. He is presently involved in several projects exploring wellbeing across the legal community and is writing the book Wellbeing, Law and Society for Cambridge University Press: richard.collier@ newcastle.ac.uk. 
J Jarpa Dawuni is Associate Professor of Political Science, Law and Gender Studies at Howard University, Washington, DC. Her research focuses on women in the legal professions in countries across Africa. She is the co-editor of International Courts and the African Woman Judge: Unveiled Narratives (Routledge, 2018) and Gender and the Judiciary in Africa: From Obscurity to Parity? (Routledge, 2016): jdawuni@ yahoo.com.

Liz Duff is Head of Westminster Law School at the University of Westminster and Director of the Centre on Legal Profession Research. Her current research focuses on the legal profession, legal education and equality and diversity: e.duff1@westminster. ac.uk.

Leny de Groot-van Leeuwen is Professor of Sociology of Law at the Law Faculty of the Radboud University Nijmegen, the Netherlands. Her research focuses on the legal profession, the judiciary and the ethics of law: L.deGroot@jur.ru.nl.

Ruth Halperin-Kaddari is Professor of Law at the Bar-Ilan University and is the founding Academic Director of the Ruth and Emanuel Rackman Center for the Advancement of the Status of Women. As an international women's rights advocate she specialises in family law, feminist legal theory, women's rights in international law, and women and religion. She was Vice-Chair of the United Nations Committee on the Elimination of Discrimination against Women (CEDAW), and has served on the committee between 2007 and 2018: ruth.kaddari@gmail.com.

Eyal Katvan is a senior lecturer, Peres Academic Center, Israel. He is a jurist, historian and bioethicist. He holds two PhDs (bioethics, law and medicine; history of medicine). His academic interests lie in the fields of bioethics, law and medicine; the legal and medical professions; legal history and the history of medicine: drkatvan@gmail.com.

Jan Kober is a researcher in law at the Institute of State and Law, Czech Academy of Sciences, Prague. He teaches (externally) at the Institute of Economic and Social History, Faculty of Arts, Charles University in Prague. His research focuses mainly on legal history, property law, family law, constitutional law, legal theory and history of legal thought. He has written on various ownership issues, on legal professions and on legal status: jan.kober@ilaw.cas.cz.

Beatriz Kohen is a sociologist and a researcher on gender and judging with a PhD from the University of Durham. She teaches at postgraduate level a course on women in the legal professions at the University of Palermo Law School, where she was in charge of the Law and Gender Programme. She has coordinated a programme on human trafficking for Argentinian judges and collaborates with the Gender Observatory of the Judicial Council of the City of Buenos Aires and conducted a large survey on gender bias in the judiciary: bkohen@fibertel.com.ar.

Xiaonan Liu is a professor at the Institute for Human Rights and the Director of the Constitutionalism Research Institute at China University of Political Science and Law where she teaches anti-discrimination law, gender and human rights. She holds an LLM from Yale Law School, as well as an LLB, Master of Law and PhD from Jilin University School of Law in China: liuxiaonan@gmail.com. 
Rania Maktabi is Associate Professor in Political science at Østfold University College in Norway where she teaches courses in international relations and comparative politics. She earned her PhD from the University of Oslo in 2012 on citizenship in the Middle East. Her research focuses on female citizenship and the relationship between state power, religion, law and politics. Her publications include Die Welt des Islams 'Middle Eastern Patriarchy in Transition' (2017) co-edited with Brynjar Lia. Her current research is on female lawyers in the Middle East and pressures to reform family law, criminal law and nationality law. She has done fieldwork and published on Syria, Lebanon, Kuwait, Qatar, Jordan, Egypt and Morocco: rania.maktabi@hiof.no.

Omnia Mehanna is an Egyptian researcher and civil society activist. Her research interests include gender, sexuality, youth, social change and political economy of development in Africa, with a strong interest in the relationship between media, particularly the internet, and these areas. Omnia holds an MA in development studies from the Faculty of Economics and Political Science, Cairo University. Currently Omnia works as Egypt country national coordinator of the African Union of Development NGOs (UAOD): omnia.mehanna@gmail.com.

Carrie Menkel-Meadow is Distinguished Professor of Law and Political Science at the University of California, Irvine and AB Chettle Professor of Law, Dispute Resolution and Civil Procedure, Emerita at Georgetown University, USA. She has published over 20 books and 200 articles on women in the legal profession, feminist legal theory, dispute resolution, legal ethics, law and popular culture and legal education. She has been a law professor for 45 years and has taught in over 25 countries. She was one of the founders of Feminist Legal Theory in the United States and before becoming a professor was a civil rights and poverty lawyer in the United States. She has received many awards for both her scholarship and teaching, most recently the American Bar Foundation Distinguished Scholar award 2018 (for her lifetime work in dispute resolution and feminism in the legal profession): cmeadow@law.uci.edu.

Mary Jane Mossman is Professor Emerita at Osgoode Hall Law School of York University. She has taught courses in law and gender, as well as family law and property law, and she has published widely in these areas and in relation to access to justice. Her research also focuses on the history of women in the legal professions: The First Women Lawyers: A Comparative Study of Gender, Law and the Legal Professions (Hart Publishing, 2006). Current research focuses on the history of early Ontario women lawyers and on 'family property' reforms: MJMossman@osgoode.yorku.ca.

Sonia Ariza Navarrete is a lawyer from the Externado de Colombia University, LLM in Comparative Law from the European University Institute (Florence, Italy), current $\mathrm{PhD}$ candidate at Palermo University. She is an external researcher at the Economy, Health and Society Department of the Centro de Estudios de Estados y Sociedad (CEDES), where she has been focusing her work on feminist legal theory and sexual and reproductive health rights: sonia_ariza@hotmail.com.

Julie Paquin is Associate Professor at the Faculty of Law of the University of Ottawa. Her doctoral degree from McGill University focused on the relationship between commercial law and development in West Africa. Her current research examines 
gender issues in the legal field, the evolution and regulation of legal professions, legal education, access to justice and the resolution of civil disputes: julie.paquin@ uottawa.ca.

María de los Ángeles Ramallo Lawyer (Universidad de Buenos Aires - UBA Argentina). Master of Arts degree from the International Institute for the Sociology of Law (Oñati). Doctoral candidate at the University of Buenos Aires and fellow of the National Research Council Argentina (CONICET). Teaching auxiliary and research assistant at UBA Law School: mariadelosangelesramallo@gmail.com.

Merike Ristikivi is Associate Professor of Legal History, University of Tartu. She has studied law (PhD) and classical philology (MA). Her main research interests are legal linguistics and discourse analysis, law journals and periodicals, Roman law, and professionalisation of Estonian female lawyers: merike.ristikivi@ut.ee.

Peter Robson LLB, PhD is Professor of Social Welfare Law at the University of Strathclyde, Glasgow. He is a solicitor and a judge in the Courts and Tribunals Service. His work focuses on the impact of popular culture on the operation of the justice system and the right to housing. He also writes and researches on the development of protections afforded by the law to minorities and less powerful groups: peter.robson@strath.ac.uk.

Kim Rubenstein is a Professor and the Co-Director of the $50 / 50$ by 2030 Foundation in the School of Business, Government and Law at the University of Canberra. She is a graduate of Melbourne and Harvard universities and works in the areas of citizenship law and public law and gender. Her work in oral history has been supported by the Australian Research Council and a Lady Davis Visiting Professorship at the Hebrew University: kim.rubenstein@canberra.edu.au.

Rupali Francesca Samuel is a human rights lawyer and researcher based in New Delhi. Her work focuses on the intersection of constitutional and criminal law. She is presently pursuing her masters in law at Harvard Law School studying feminist legal theory and anti-discrimination law:pali.samuel@gmail.com.

Emily Sanchez Salcedo is a Professor at the Commercial Law Department of De La Salle University in the Philippines. She has written extensively on the status of women in the Philippines with special focus on gender discrimination in the workplace. Her recent work lies at the intersection of gender and the legal profession as well as gender and legal pedagogy. Prior to joining academe, Professor Salcedo was a seasoned litigator specialising in family law practice: emily.sanchez@dlsu.edu.ph.

Ulrike Schultz is a retired lawyer and senior academic at the FernUniversität in Hagen, Germany. She specialises in questions of gender and law, the sociology of the legal profession and didactics and professional communication. She has taken part in many international socio-legal projects, and conducted big empirical studies on, for example, Women's Careers in the Judiciary and Women in the Legal Academy. She heads the Working Group on Women/Gender in the Legal Professions, has been a member of the Oñati International Institute for the Sociology of Law Governing Board since 2006 and is President of the Research Committee for the Sociology of Law (RCSL): www.ulrikeschultz.de; Ulrike.Schultz@FernUni-Hagen.de. 
Harriet Silius is Professor Emerita in Women's and Gender Studies at Åbo Akademi University, Finland. She is a long-standing member of international research committees and working groups on Sociology of Law and Sociology of Professions. One of her fields of expertise is the comparative study of gender relations in working life, especially in the Nordic welfare societies: Harriet.Silius@abo.fi.

Hilary Sommerlad is Professor of Law and Social Justice, Leeds University. Following a history degree (Cambridge), and PhD in Political Science (York), she retrained in law and practised as a legal aid solicitor. She then taught criminal and public law and developed socio-legal research at the universities of Leeds Beckett, Leicester and Birmingham. She is Fellow of the Academy of Social Sciences, chairs the sub-group on Legal Professional Values and Identities of the RCSL Working Group on the Legal Profession and is a founder member of the Judicial Diversity Initiative: judicialdiversityinitiative.org/. She has published widely on the legal profession and access to justice, and is currently co-editing, with Richard L Abel, Ole Hammerslev and Ulrike Schultz, the second volume of Lawyers in 21st Century Societies (Hart Publishing): H.A.K.Sommerlad@leeds.ac.uk.

Nadia Sonneveld has an academic background in anthropology, Arabic and law. She is affiliated to the Van Vollenhoven Institute for Law, Governance, and Society, Leiden University, the Netherlands. Previously, she was a guest scholar at the School of Oriental Studies (SOAS) in London, and Al-Akhawayn University in Ifrane, Morocco. The common factor in all her research activities is the focus on gender and law in Muslim-majority countries, particularly in Egypt and Morocco. In her most recent research project 'Living on the Other Side' she focuses on the rights of migrants in Morocco through the lens of family law: n.sonneveld@law.leidenuniv.nl.

Jennifer Temkin LLD is Professor of Law Emerita at Sussex University and has been Professor of Law at the City Law School, City, University of London for the past eight years. She has written extensively about criminal justice matters. She is a member of the Biometrics and Forensics Ethics Group sponsored by the Home Office. She is a Fellow of the Academy of Social Sciences and was made a CBE in 2018 for her contribution to criminal justice: J.temkin@live.com.

Margaret Thornton is an Emerita Professor of Law at the Australian National University. She is a socio-legal and feminist scholar who has published extensively in the areas of legal education, the legal profession, discrimination law and feminist legal theory. She is a Fellow of the Academy of Social Sciences in Australia and a Foundation Fellow of the Australian Academy of Law: margaret.thornton@anu.edu.au.

Hans den Tonkelaar was senior Judge in the District Court of Gelderland, the Netherlands. He was also Professor of Law at the Radboud University in Nijmegen, the Netherlands: j.dentonkelaar@jur.ru.nl.

Lisa Webley is Chair in Legal Education and Research and Head of Birmingham Law School at the University of Birmingham and Senior Research Fellow at the Institute of Advanced Legal Studies, University of London. She is Head of Research in the Centre for Professional Legal Education Research (CEPLER) at the University of Birmingham. Her current research focuses on legal education, the legal profession, legal ethics, access to justice and equality and diversity: L.C.Webley@bham.ac.uk. 
Celia Wells, OBE, is Emerita Professor of Criminal Law at the University of Bristol. Celia's research specialises in criminal law, corporate criminal liability and she has also written about gender in legal education. In a career spanning 40 years she has held a number of management roles, given expert advice on corporate criminal responsibility to national and international bodies, and held visiting positions in Australia and the US: Celia.Wells@bristol.ac.uk. 


\title{
The Way to Barbara Armstrong, First Tenure-Track Law Professor in an Accredited US Law School
}

\author{
SUSAN D CARLE
}

\begin{abstract}
This chapter traces the history of 'firsts' among women law professors in the United States. It discusses several possible such 'firsts', steering away from designating a winner. One theme in this historical story is that the dismantling of gender-based barriers took place through several avenues; another is that 'firsts' did not necessarily signal lasting change in opening paths for women into law teaching. That change arguably happened when Barbara Nachtrieb Armstrong was appointed in 1919 as the first woman to hold a tenure-track position in an accredited US law school. Professor Armstrong taught at the University of California at Berkeley, where she had a dual identity, holding both a JD and a PhD in economics. The fact that she straddled two academic disciplines may have helped her navigate her status as a female; she was already an outsider who did not fit completely in either of her disciplinary homes. Armstrong also possessed a third identity, as a policy advocate and social reformer. Along with her academic achievements, she served as the primary drafter of the Social Security Act of 1935. In this role her insights as a constitutional law professor blended with her economics background. She succeeded in envisioning a new national system for old age insurance that could withstand constitutional challenge despite the strong rights granted states under the US Constitution. Armstrong faced gender-based barriers in her work. She was criticised for being abrasive, a characteristic that may have allowed her to break through gender barriers while also sometimes being a liability that reflected a double standard or stereotype about acceptable gender performance. Armstrong's story provides important lessons in confronting continuing gender bias in the US law professorate today. Although women have made much progress, signs of continuing discrimination remain, including evidence of salary disparities and lower prestige for the types of academic positions women are more likely to hold.
\end{abstract}




\section{THE PROBLEM OF FIRSTS}

$\mathrm{R}$

ESEARCHING 'FIRSTS' IN women's legal history presents a somewhat vexed topic. Why should firsts be more important than seconds, or thirds, or number ten, or the first one hundred? How much luck is involved in being first? To what extent do firsts illuminate explanatory factors, such as changing historical circumstances; individual characteristics, such as special drive and/or talent; or social factors, such as greater privilege, providing better access to opportunity? These are some of the difficult questions that arise in 'firsts' projects, but they need not derail them. The stories of firsts are illuminating even if they do not provide definitive answers to how change occurred or why.

This report discusses several female 'firsts' in the US law school professorate. It steers away from designating any one as the 'winner', since one theme in the story of US women's entry into law professor jobs is that these achievements took place through several avenues. Understanding women's entry into the US legal academy requires a short historical look backwards. US legal education and legal academia differ from European models in large part because of this history.

\section{A THUMBNAIL SKETCH OF THE HISTORY OF US LEGAL EDUCATION AND ITS PROFESSORIATE}

In the first half century of the United States existence as a new country, anyone who wanted to practise law or call themselves a lawyer could do so in almost all states (White 2016: 313). As the decades passed, more states began to require lawyers to 'sit' for the Bar by appearing before a committee of judges who evaluated their fitness for practice. These committees probed applicants' legal knowledge and evaluated their 'character' - which ensured exclusion of outsiders on the basis of race, gender and social class (Carle 2013: 33). Lawyers typically prepared for the Bar by apprenticing with practising lawyers (White 2016: 313; Stevens 1983: 24).

In the $1820 \mathrm{~s}$, a few educational entrepreneurs experimented with establishing forprofit law schools, but these failed because a law degree was not required to practise law (White 2016: 313). Law school as an institution began to arise in the US in the 1850 s, as young men of means began to find them a convenient way to prepare for the Bar, even though graduation still was not required for Bar admission (Stevens 1983: 21). The number of law schools increased through the second half of the nineteenth century as law students with high social privilege enrolled in greater numbers.

Universities housed a few prestigious law schools, such as Harvard Law School, which became the model for elite legal education. Even there, most law school faculty members were part-time and maintained their hand in legal practice. This was even truer of law instructors at non-elite institutions, who often taught for very little pay. Such law schools for less privileged students began to spread in the last decades of the nineteenth century, responding to a growing demand for part-time and/or night programmes for students who could not afford the luxury full-time study (Stevens 1983: 74). Most of these schools were 'independent' (meaning that they were not affiliated with universities), and they catered not only to students who could not afford 
the cost of more elite education but also to those who would have been denied admission at traditional schools because of their gender, race, ethnicity, recent immigrant status, or a combination of these factors. It was these non-elite schools that offered the first points of entry for female law teachers, as we shall see below.

A peculiar feature of US law schools as they developed in the late nineteenth century concerned their predominant method of instruction. Early in the century, law students read, memorised and then recited portions of legal treatises as their means of gaining knowledge about the law. In 1870, Christopher Columbus Langdell became Law Professor and Dean at Harvard Law School, where he began to champion a method for legal education that he called the 'case method'. The case method called on professors to assign selected appellate case opinions as readings, and then to engage in a process of questioning students in the classroom to steer them in analysing and synthesising the doctrines they excavated from cases (Kimball 2009: 131). Langdell and other professors began publishing their case compilations as 'casebooks', and this method of law teaching became predominant in US law schools, where it continues today. The spread of the case method pedagogy explains why US legal education did not emulate European models.

Throughout the nineteenth century, no law school accreditation body or process existed in the US. Law schools set their own policies regarding admissions, length of study, curriculum and all other matters. Requirements varied greatly depending on the type of students a law school hoped to attract, leading to significant stratification among various programmes (Stevens 1983: 76). In 1878, the American Bar Association (ABA) was formed as a national Bar association for the professional elite. In 1893, it formed a section on legal education (Harno 1953: 80). With a combination of public interest and monopoly-protecting motives, the ABA began to concern itself with the quality of legal education, advocating especially for more restrictive standards for law school admissions (Stevens 1983: 93; Harno 1953: 80-86). Most law schools at the time did not require applicants to hold a four-year undergraduate college degree before entering; the ABA argued that persons eligible for Bar admission should have completed college as well as law school education.

In 1900, elite law schools formed their own organisation, called the Association of American Law Schools (AALS), to advocate for their institutional interests as well as the interests of elite law professors, who by this time were becoming a full-time, academically focused group. These law professors wanted regulatory standards to promote their ability to pursue scholarship and to guarantee them job security through lifetime tenure (Harno 1953: 94). The AALS also opposed part-time law study and sought to impose other constraints on market competition. In these respects, the ABA and the AALS's interests converged, and each organisation lobbied state legislatures to tighten standards for legal education and Bar admissions (Stevens 1983: 38, 99; Harno 1953: 97-102).

The AALS's first list of 'approved' (or member) law schools, which it issued in 1923, contained 39 institutions and another nine with provisional status; in comparison, more than 142 law schools operated in the US in 1921 (Stevens 1983: 173-74, $181 \mathrm{fn}$ 12). In 1927, the ABA had accredited 65 law schools. This list corresponded closely to the list of AALS-member schools; thus, the ABA had accredited less than half of the 175 law schools in operation (Harno 1953: 112-13). In 1928, only 
a third of US law students were in AALS-member law schools (Stevens 1983: 174). Thus, law schools could (and a few still do) operate without gaining membership in the AALS or accreditation by the ABA.

In a later era, the ABA and AALS began working even more closely together in evaluating law schools for accreditation. Over time, a far greater percentages of US law schools became ABA-accredited and AALS members. Today the vast majority of US law schools hold both these credentials. With these developments, regulators began to impose more uniformity on law schools as well as more pressure to promote scholarship and to use tenure processes that evaluate scholarship as well as teaching. Today, volunteers from the ABA and the AALS conduct law school site inspections for accreditation and re-accreditation, though each law school continues to set its own criteria for the entry-level qualifications required for new faculty members. Similarly, each US law school defines its own faculty tenure standards, which tend to focus on demonstrated excellence in teaching, scholarship and public and professional service, as weighted somewhat differently by different institutions. Thus, as compared with some other countries, US legal academia remains relatively diversified - and stratified both in terms of law schools and the paths by which law professors come to obtain highly coveted positions in legal academia. This institutional diversity helped propel women's participation in US legal academia, as explored further below.

\section{WHO WAS FIRST?}

US legal historians have debated who should be counted as the 'first' female legal academic. The candidates fall into two categories. One category consists of 'firsts' who founded and/or taught in law schools that were themselves breaking barriers by providing legal education to outsiders - in other words, to students who were not welcome in established schools by virtue of their social identities. Another category consists of 'firsts' who broke the gender barrier to acceptance of women law professors on an equal, tenure-track basis in the law schools the AALS approved. Although historians of women's legal history sometimes dispute which category's members should truly be considered 'firsts', this question need not be answered for purposes of this report. Women in both categories were firsts in their respective contexts, and all of these women were important pioneers.

Some historians view African American law professor Lutie (sometimes referred to as Edna) A Lytle as the first woman law professor in the United States (Smith 1993: 353; Sheppard 1999: 915). Lytle (b 1875, d 1950) was an early African American female law school graduate. She received her law degree in 1897 from the Central Tennessee College Department of Law, which had been founded by the Freedman's Bureau, a federal agency set up after the end of the US Civil War to educate newly emancipated African Americans as they assumed the responsibilities of citizenship.

\subsection{Lutie Lytle}

Unlike most of the handful of other African American women who graduated from law school in this very early period, Lytle's family did not hail from the free black elite. 
According to newspaper reports, Lytle's father had been enslaved before the war in Tennessee. Scant information exists about her mother. Lytle's family was part of the Exoduster movement, a migration of African Americans from Tennessee to Kansas in 1879 in response to the continued oppression of African Americans in southern states after the Civil War. There Lytle's father became, according to several accounts, 'one of the wealthiest colored men in Kansas', and Lytle received 'the best education that could be furnished by the non-segregated public schools of Topeka' (Salt Lake Herald 1897a). Lytle's family was active in the Kansas People's Party, which was attempting to organise a racially inclusive Populist movement in that state in the mid-1890s.

In 1895 , at the age of 20, through her father's political connections, Lytle was appointed the party's assistant enrolling clerk in the Kansas State Legislature. She also worked as a typesetter at a local African American newspaper, where she met many political figures and community leaders. She later reported in a newspaper interview that it was this work that led her to seek a Bar licence, explaining,

I conceived the idea of studying law in a printing office where I worked for years as a compositor. I read the newspaper exchanges a great deal and became impressed with the knowledge of the fact that my own people especially were the victims of legal ignorance. I resolved to fathom its depths and penetrate its mysteries and intricacies in hopes of being a benefit to my people (Kansas Historical Society 2004).

In 1896, Lytle took a position teaching school children in Tennessee, where the Central Tennessee College was admitting African American law students. Lytle used her earnings as a school teacher to enrol in the College's fledging Law Department, which had only two students including herself. In September 1897, she passed an oral exam to gain admission to the criminal court in Memphis, Tennessee. This achievement granted her minor celebrity status for becoming, at the age of 23, the first African American woman licensed to practise law in Tennessee (Iowa State Bystander 1897; Salt Lake Herald 1897b; Vermont Phoenix 1897: 10). As one newspaper noted, it was 'rather remarkable that the first colored woman to be admitted to the bar in the United States should have been admitted in an old slave-holding state, one would have thought she would have been admitted in some old abolition state, Massachusetts or Ohio' (Salt Lake Herald 1897a).

After graduating Lytle also gained admission to the Bar in Topeka, Kansas, her home state. She reportedly toyed with the idea of setting up a law practice to pursue constitutional law claims there, and she also announced her desire to seek a law partner in Chicago, though the newspaper that published these plans on its front page ridiculed her for them (St Paul Globe 1897: 1). These aspirations apparently quickly came to naught; that summer she would tell a newspaper that she had realised that professional African Americans were having more success in medicine than in law (Topeka Daily Capital 1897).

In the fall of 1898 Lytle accepted a position as a faculty member of the Central Tennessee College Department of Law, to teach subjects including domestic relations, evidence, real property, crimes and criminal procedure. This gave her the distinction of becoming the first female law professor in the country according to contemporaneous accounts (The Evening Times 1889). Lytle taught there for only one year; she later married and moved with her husband to New York, where she was active in the African American women's club movement. She remained politically active in other 
ways as well, attending the National Negro Bar Association Annual Convention in 1913 and becoming a supporter of Marcus Garvey, the leader of the Universal Negro Improvement Association and its Back to Africa movement, in 1920 (Henderson 2017: 2008-12; Ali 2008: 438-29; McLeod 2005: 3).

This evidence about Lytle's short-lived law teaching experience, limited as it is, illustrates several important facts. First, the most open points of initial entry into law teaching for women involved outsider spaces. At the same time, those spaces provided tenuous berths. The same race and class dynamics that defined spaces as outsider territory also diminished the status and desirability of those positions. Certainly, Lytle's time as a law teacher was exceedingly short, but that is part of what her case reveals: gender, race and class status played into a mix of factors that gave this 'first' an opportunity, but not staying power, in the legal academy.

\subsection{Ellen Spencer Mussey and Emma Gillett}

Other contenders for the title of first women law professors are Ellen Spencer Mussey and Emma Gillett, who founded an initially independent, unaccredited law school, named the Washington College of Law (WCL) in Washington, DC in 1898. They founded WCL because all of the established, whites-only, law schools in the nation's capital refused to admit women. The only law school that did admit women was Howard University Law School, another Freedman's Bureau school founded at the end of the Civil War to educate newly emancipated African Americans. Howard Law School did accept white women - indeed, it accepted far more white women than African American women. Howard had even awarded Gillett her law degree in 1882 (Smith 2000: 54). Gillett and Mussey believed, however, that white women should not have to attend law school with black men. This gender-progressive, but racially discriminatory, motivation accounts for the founding of WCL, which denied admission to African American students until 1950, when it sought AALS membership and ABA accreditation after merging with American University, a private Methodist university seeking to affiliate with a law school (Clark 1998: 657).

Mussey and Gillett were no pioneers on issues of race, but they were pioneers in other ways. Mussey had been born in 1850 in Ohio, was educated in several all-female seminaries where she paid tuition by teaching penmanship, and then married RD Mussey, a prominent Washington, DC, lawyer (Clark 1998: 616-17). The Musseys were of high enough social status to attend parties at the White House, and Ellen Mussey at first held the conventional beliefs of women of her station, including the view that only men should practise law.

After her husband fell ill with malaria, however, Mussey began to help him with his practice. She continued to do so for many years, even after he recovered. When he died in 1892, she took over his law office. At this juncture she needed to become a licensed lawyer since she could no longer 'assist' with legal matters under her husband's name. Mussey found no local law school willing to admit her so that she could obtain automatic admission to the Bar, which at the time was permitted only for law school graduates. Eventually, a judge she knew granted her Bar admission after giving her an oral examination at her home (Clark 1998: 622). 
Mussey's practice was reportedly in private and public international and business law. As she grew into her identity as a female lawyer practising on her own, she began to take on political issues too, including proposing legislation to grant married women the right to own property, which became known as the Mussey Act and became law in 1896 (Clark 1998: 624).

Gillett, two years younger than Mussey, was born and raised in Pennsylvania, where she also received her education in an all-female seminary. She developed an interest in law after a decade as a public school teacher in Pennsylvania. Hoping for a higher salary as a lawyer, she enrolled in and graduated from Howard Law School. She then sat for and passed the Washington, DC, Bar exam. She joined a law office, where she practised real estate and pension law for two decades.

Like Mussey, Gillett enjoyed mentoring other women interested in law, and in 1896 she joined with Mussey to establish a 'Women's Law Class', through which the two women helped other women with legal studies without awarding academic credit. This project led them to decide, some two years later, to found together the Washington College of Law as a credit-awarding institution (Clark 1998: 625-27).

Gillett and Mussey took turns being dean of WCL and served as law professors there, all the while engaging in suffrage and other work promoting the rights of women and women in the legal profession. American University Professor, Senior Vice Provost and Dean of Academic Affairs Mary Clark has well explored this history (Clark 1998).

In sum, one category of US female law professor 'firsts' taught students who otherwise would have had been excluded from law schools, and worked in schools founded for this purpose - in other words, in outsider schools for outsider students. These schools lacked the resources and support for scholarship that characterised the elite, accredited schools in which many traditional insiders received their legal education. The law teachers in non-AALS affiliated schools had little reason to organise their professional priorities in intensely scholarly directions. Their law teaching positions did not grant them entry into so-called 'elite' legal academic circles. AALS-accredited law schools, on the other hand, continued to exclude women, especially from high status teaching appointments. Over time, more of these schools had women lecturers on staff, who serviced students by teaching necessary courses. Yet AALS-member schools still barred women from gaining the highest status positions in law teachingnamely, as full-time professors doing scholarship and in turn receiving lifetime tenure.

It would take further developments to crack open this door. While some women gained short-term, often part-time, teaching appointments as 'lecturers', it was not until 1919 that a woman started teaching in a major, AALS-approved US law school on the tenure track. That woman was Barbara Nachtrieb Armstrong.

\section{BARBARA NACHTRIEB ARMSTRONG}

Barbara Armstrong started teaching at the University of California at Berkeley Law School, known as Boalt Hall, in 1919. She received promotion to full professor with tenure in 1935. In between, she drafted a path-breaking book and one of the most important pieces of social welfare legislation in US history, the Social Security Act 
of 1935 (SSA). Unlike Lytle, Mussey and Gillett, Armstrong had the resources to conduct extensive scholarship, producing over her full career several books and numerous important scholarly articles and policy papers. Unlike these three other firsts, Armstrong taught in a traditional law school, to large classes of students. Like these other firsts, however, Armstrong's passion for social reform provided her with special motivation for her work and, also like these others, she sought to instil some of her reformer perspective in her students.

Unlike Lytle especially, Armstrong has not been lost to US legal historians. Others have recognised her major role in drafting the SSA and her status as a pioneer in women's entry into legal academia (Lopez 1987; Dauber 2013; Kay 1991). However, little scholarship explores the connections among Armstrong's gender, her pioneering status as a legal educator, and her role in shaping US social welfare law.

\subsection{Barbara Armstrong's Early Life and Education}

Barbara Nachtrieb Armstrong was born in San Francisco, California, in 1890. Her parents were German immigrants. Little information illuminates Armstrong's childhood. She went to public (ie, free, taxpayer funded) schools as a child, and then entered college at the University of California at Berkeley, an excellent state-funded school. In college, she became fascinated with the subject of social insurance. She took a course called control of poverty and recalls that her professor 'talked only about assistance and ... holding poverty down by giving good relief'; in turn Armstrong 'raised the issue with the professor that you didn't control poverty unless you got at the cause of it and stopped it where it started' and suggested that public relief was a 'social vice'. She 'got squelched hard', as she recalled, but said to herself 'nevertheless I'm right, there must be a better way to do this' (Armstrong 1965: 2).

Armstrong graduated from Berkeley in 1913, and enrolled in its Boalt Hall Law School, even though it was rare for women to attend law school at that time (Traynor et al 1997: 927). Boalt was an elite public institution, which in the 1920s sought to distinguish itself by adopting a 'functional' approach to legal studies that emphasised the social sciences (Stevens 1983: 147 fn 56, 213). After graduating from Boalt, Armstrong went into law practice with another female classmate and became friends with Katharine Felton, who directed a large organisation called Associated Charities in San Francisco. Felton came from a prominent San Francisco family and was working to set up more effective social service programmes there (Burton 1947). Armstrong and Felton shared similar views about the need to find new approaches to social welfare and, in 1915, Armstrong's connection with Felton led California's governor to appoint Armstrong as the executive secretary of a commission on social insurance. The Commission identified two basic causes of poverty: substandard wages and lack of protection for times when a worker did not have a wage. It determined that sickness was the greatest single cause of destitution and recommended that the state extend its workers' compensation programme, which covered workplace injury only, to illnesses of any cause - thus in essence recommending compulsory health insurance for California. The Commission put its recommendations to a vote in a statewide referendum in 1917, but they were defeated (Armstrong 1965: 4-5, 25). 
After the Commission wound down its work in 1919, Armstrong went back to Berkeley, enrolled in its Economics Department for PhD studies, and began teaching courses in both the Law and Economics departments. These courses on social legislation allowed Armstrong to further develop her ideas about how social insurance programmes could prevent poverty while promoting human dignity and self-respect (Armstrong 1965: 43). Armstrong received her $\mathrm{PhD}$ in 1921, using as the basis for her dissertation the Commission report she had written for the state of California (Armstrong 1965: 20).

\subsection{Armstrong as a Law Professor and Economist}

The fact that, by 1919, Armstrong was serving as a lecturer at Berkeley in both the law and economics departments arguably makes her the first female law professor 'at a major university' (Traynor et al 1977: 927). But she has an even greater claim to the status as a 'first' in US legal academia, in the following way: uinlike other early women law teachers who remained trapped in lecturer roles despite strong credentials and accomplishments, Armstrong managed to be the first to break into a tenuretrack position at an AALS member school in 1928 (Kay 1991: 5), after which, in 1935, she became a full professor with tenure. ${ }^{1}$ Scholars have presented these basic facts about Armstrong's status, but no one has yet explored the connections between Armstrong's status as a 'first' in US legal academia and her significant role in creating US social policy. Had Armstrong been male, such a treatment of her as a legal intellectual might have appeared long ago. The remainder of this report draws this picture of Armstrong as a law professor situated in a particular gendered historical context, who exercised political will and engaged in legal intellectual innovation along with her professorial role.

Armstrong remained at Boalt throughout her teaching career, where she was a beloved professor, teaching constitutional law, social welfare law, family law and labour law. Early in her career, she published a deeply researched comparative study of social insurance programmes in various countries in Europe, Scandinavia, Australasia and the Americas. This work, titled Ensuring the Essentials: Minimum Wage Plus Social Insurance - A Living Wage Program, was published in 1932 while Armstrong was an associate professor and established her as a serious scholar, one of a small group of national experts on the design of social insurance programmes. To write the book, Armstrong travelled to Europe with her family, spending a year ensconced in the Bibliothèque Nationale in France and brushing up on her languages in order to

\footnotetext{
${ }^{1}$ In US legal education, law teachers have various statuses. The highest status instructors are full professors with tenure. Instructors can be hired 'on the tenure track', which means they have scholarship requirements and, if they meet their institution's standards for amount and assessed quality of scholarship, will become full professors with tenure after a period that can range from five to seven years. Professors with tenure have high job security and privilege. Other instructors in law schools are not eligible for tenure. These are sometimes called 'lecturers', and typically provide subject coverage in areas in which a law school needs courses. They typically have far less, if any, job security and may or may not produce scholarship. For many decades in US legal education, women were typically hired as lecturers even when they held the same academic qualifications as men hired for tenure-track jobs.
} 
read sources in the original (Armstrong 1965: 26). She described this research as 'quite a job' but depicted herself as 'very tough' as a young person, and industrious due to her 'German blood', which gave her the 'self-discipline and all the rest of it' that she found a great help to her throughout her life (Armstrong 1965: 27).

Ensuring the Essentials was undoubtedly the reason for Armstrong's appointment as the Chief of Staff for Social Security Planning of the Committee on Economic Security (CES) in 1934. As she explained to her oral history interviewer, she had no special political connections in Washington, DC, and thus no means to have received her appointment through political means. Instead, a progressive business person she knew in California, who had read and liked her book, passed it on to the President, Franklin Delano Roosevelt (FDR). This fortuity, Armstrong believed, was the reason she found herself in the position to implement her strongly held ideas about comprehensive national social insurance through her appointment to the CES in Washington, DC, which in turn led to her drafting of the Social Security Act of 1935 (Armstrong 1965: 30).

\subsection{Armstrong as a Policy Advocate: Drafting the Social Security Act of 1935}

The CES was a cabinet-level committee appointed by FDR and chaired by Secretary of Labor Frances Perkins, who was the first female cabinet level officer in the US government (Downey 2009: 114). Edwin Witte, an economics professor at the University of Wisconsin with a history of public service and reform activism, served as chief of staff and brought in Armstrong as well as other experts (Smith 2014: 89-90).

Armstrong readily accepted the invitation to serve on the CES, even though it meant leaving her family, which consisted of her husband, Ian Armstrong, and a daughter Patricia (Traynor et al 1977: 924). She remained in the nation's capital for approximately six personally lonely but professionally productive months. Armstrong, as already noted, was against social welfare policies that smacked of charity. Instead, she championed the social insurance concept - ie, that, before anyone could foresee their lot in life, such as whether they would live long or die early, become ill or injured or live a healthy life, all would contribute into an insurance pool to provide for those who would turn out to be less fortunate. To Armstrong, working in the middle of the Great Depression, national social insurance was not only actuarially necessary but also essential to the protection of human dignity. Insurance arose from communal solidarity in which all participated on equal terms; welfare payouts, in contrast, demeaned recipients and robbed them of their self-respect.

Armstrong was an ardent champion of these beliefs and had a reputation for having a forthright personality, which some found abrasive at times. Armstrong may have been perceived as abrasive where she was merely being assertive. She described, for example, an early meeting in Washington, DC, at which 'they talked as if I were a chair. They paid no attention to me' (Armstrong 1965: 224). Moreover, it is clear that her reputed abrasiveness was not constant; her many close friends at Boalt Hall had extremely favourable views of her and her students adored her (Traynor et al 1977).

Several examples illustrate Armstrong's personality and show the success she sometimes achieved by adopting an outspoken and unrelenting manner. One concerned 
FDR himself: at a press conference he held on 14 November 1934, to discuss CES's work, he stated, in an apparent attempt to appease conservatives, that the time was not right for federal legislation on old age security and that the Committee would focus on unemployment insurance instead. Aghast that the Committee might take this direction, Armstrong reportedly shouted out in front of reporters, 'This is the kiss of death'. Armstrong had worked to cultivate press contacts through a friend who introduced her to all the women journalists in town. Although they tended to be conservative, these women held a strong sense of 'sex solidarity' and 'slanted the story whenever possible' to help her (Armstrong 1965: 158). Armstrong's statement at the President's conference received much press attention and, in Armstrong's view, helped push the President to agree to a national plan for old age insurance.

Another example of how Armstrong's forthright manner helped her navigate the difficult politics of serving on the CES concerned her ongoing battles with other staff. Armstrong and Witte did not get along well together; Armstrong felt Witte demeaned her and did not give her due respect, and she did not hold him in high regard either, describing him as 'inadequate' (Armstrong 1965: 86). The disagreement between Armstrong and Witte came to a head in writing legislation, as the Committee discussed the constitutionality of a national old age insurance plan. Eliot claimed a national plan would run into constitutional objections, but Armstrong disagreed, having to remind Eliot that she was a constitutional law professor as well as an economist, which he claimed not to have realised (Armstrong 1965: 75). Thomas Eliot, chief legal adviser, reported in a staff meeting that even pre-eminent Harvard constitutional law professor Thomas Reed Powell, who was known for his liberal views on constitutional issues (Powell 1967), thought that a state federal plan would be more constitutionally sound that a national plan. In response, Armstrong swung into action. As it happened, Armstrong was personal friends with Powell, and she took an all-day train trip to Boston to pay a surprise call on him. Receiving her in his library, Powell disavowed ever having said anything like Elliot had reported, and agreed to write a letter stating that he viewed national old age insurance as constitutional.

Armed with this letter, Armstrong attended the next CES staff meeting and handed it across the table to Eliot. Turning white with chagrin as he read it, Eliot asked Armstrong to read the letter out loud and she did so, stating to the Committee in conclusion, '[n] ow we should go on with the assumption that everything is possible' (Armstrong 1965: 98). Armstrong then secured endorsements for her proposed approach from other constitutional law professors as well, and these, along with Powell's especially telling letter, settled the constitutional fight within the Committee. Eliot never raised the issue again (Armstrong 1965: 1010). This anecdote illuminates Armstrong's will and energy, which in turn explains why she is so deeply regarded as the forceful mastermind and architect of the US Social Security Act of 1935 (Dauber 2013: 137). Despite her tiffs with Witte and Eliot, Armstrong largely got her way in designing that Act, drafting an old age insurance bill that established a programme run entirely by the national government.

Nevertheless, the legislation faced significant risks of constitutional challenges. It was not clear that the Court would see it as a proper exercise of Congress's powers to regulate interstate commerce because the bill promoted social welfare, a purpose to which the Court had shown itself to be quite hostile in a series of past decisions 
concerning the limited scope of national power (Lopez 1987: 8). Armstrong might have attempted to aid in the legislation's passage through Congress by remaining in Washington, DC, but she chose not to do so. Displaying self-insight, she did not testify before Congress to defend her handiwork because she thought her personality might be too abrasive. Instead, eager to reach her home in time for Christmas with her family, she departed from Washington, DC, by train in December 1934, never to return (Armstrong 1965: 203). Armstrong regarded her experience with Washington to be over, and seemed relieved of it. Although her bill was changed in legislative committee in a number of ways, its basic architecture, including important features that allowed it to withstand constitutional challenge in 1937, remained unscathed. With many details changed but its basic design and structure relatively untouched, the Social Security Act of 1935 remains intact today, providing an important source of income in old age for many US residents.

Back in California, Armstrong was far from finished with social policy activism. She wrote an article defending the constitutionality of the SSA (Armstrong 1936), which proved prescient when the US Supreme Court upheld both its tax and the benefits provisions in a pair of important cases that helped reconfigure US constitutional jurisprudence (Steward Machine 1937; Helvering 1937). Those decisions paved the way for other important New Deal programmes responding at a national level to complex, ever-changing social problems (Lopez 1987: 11).

Armstrong was a constitutional law professor, but her outsider status helped her see the need for social policy and constitutional law change. Many factors contributed to her vision, including her dual identity as an economist and lawyer, her passionate commitment from an early age to advancing European-style social insurance design, and her reform experience and exposure to role models of other middle-class women situated in a historically specific community of social reformers (Muncy 1991; Gordon 1989).

Armstrong's next major activist commitment was to universal health insurance in California (Armstrong 1965: 14-17). She joined a community of committed reformers and served as a role model for rising generations, working with other professors at Berkeley to define the elements of a good health insurance programme (Diepenbrock 1994: 60-61). Their efforts to pass health insurance legislation in California were unsuccessful, but their work was a precursor to the passage of the US Affordable Care Act in 2010. Armstrong foresaw the importance of national health insurance guarantees. To this day, Americans are still fighting these policy debates, in politics and in law.

\subsection{Armstrong's Later Life}

Armstrong remained on the UC Berkeley faculty for several more decades. In 1955, she was appointed to the AF and May T Morrison Chair of Law. Her personality traits of strong opinions and forthright speech served her well in the classroom. She was known as an 'extremely gifted teacher', with an 'animated teaching manner', who hosted lively classes in which she frequently had to appoint a student sergeantat-arms to maintain order (Traynor et al 1977: 928). She inspired students in her 
teaching areas of labour and family law, and enjoyed following her former students' professional and personal accomplishments. One of her former students described her as 'not content to teach only what was contained in statute books or court decisions'; instead, she 'always analyzed the law in light of what she thought it should be. She then proceeded to mobilize her students and colleagues to work for its change' (Traynor et al 1997: 934). Like her students, Armstrong's colleagues found her a 'constant ferment of ideas ... expressed so vividly' - a 'delight to see and hear' (Traynor et al 1977: 928, 930).

In 1953, Armstrong published an important two-volume work, entitled California Family Law (Armstrong 1953). This book proposed reforms later adopted (Traynor et al 1977: 934). She continued to hold various state and national public service appointments too, though none as important as her work on the SSA (Armstrong 1965: 935; Traynor et al 1977: 928, 935).

Although she had been an intellectual and social policy pioneer in her lifetime, Armstrong did not like the 1960 s social revolution. She opposed the frequent student sit-ins and anti-war protests on the Berkeley campus in the 1960s, and found it strange to be no longer regarded as a liberal (Armstrong 1965: 287). Armstrong's strength of character led her not to flex. In her later years, after her husband died, she insisted on continuing to live in her neighborhood near the law school in Oakland, which had changed much through a period of urban turmoil. In February 1970, at the age of 79, three men robbed and savagely beat her, leaving her for dead (Traynor et al 1977: 926). She managed to crawl to help, but never recovered her good health and lived in constant pain for the last six years of her life (Traynor et al 1977: 926).

Armstrong died on 18 January 1976, at the age of 85. Her life had spanned more than three quarters of a century, during which she had played a prominent role in the coming of the US New Deal social welfare state. She also experienced its failure to solve the problems of poverty and destruction of human potential that she had so passionately given her life to ameliorating. She was, in every sense, a pioneer.

The question of how Armstrong's gender influenced her life and accomplishments is, of course, a difficult one. It would be far too simplistic to assert that gender determined her life outcome, but gender surely played a role in her interest in social insurance and social welfare policy, in subtle and complex ways. Like female students of her generation around the country, Armstrong as a college student faced a paradox: avenues of higher education were opening to women, but women still faced high discriminatory barriers to professional success (Carle 2013: 26). Like other female students of her generation, Armstrong learned about young middleclass women's involvement in social welfare work. This work drew motivation from materialist ideologies of women as mothers for the nation, who would handle as policy matters the nurturing of the nation's residents and the provision of social welfare programmes to protect against human misery and harm (Muncy 1991; Gordon 1989).

Gender clearly presented a barrier for Armstrong too. As the first tenure-track female law professor at an AALS-member law school, Armstrong broke through a barrier. It is difficult to pinpoint why she was first, but likely factors include merit, education, ability to devote time to research in Europe to write her path-breaking book, and her straddling of two academic disciplines as an economist and a law 
professor. Perhaps significantly, she played to her economist identity early in her career, so much so that Witte did not know she was a law professor.

Only later in her career did Armstrong turn to writing books on family law. This may have been a coincidence but may also have been strategic, to avoid being typecast as a professor concerned with 'women's' issues. Armstrong may have wanted to make family law a more important and valued subject. Her books, among the 'firsts' on the subject in the US, became a basis for much scholarship that occurred later in the field.

\section{EPILOGUE: WOMEN LAW PROFESSORS IN THE US TODAY}

Today, almost 120 years since Lytle, Mussey and Gillett first embarked on law teaching and more than 80 years since Barbara Armstrong received tenure, the picture regarding women's status in US legal academia remains a complex blend of progress mixed with continuing discrimination. In 2013, the latest date for which data are available, women constituted 33 per cent of tenured law professors (ABA 2016). This statistic appears to show continuing female underrepresentation, although one analyst has pointed out that women are over-represented as law school professors as compared with the relevant labour pool of women with law degrees (Lindgren 2016: 140). Earlier studies of the results of so-called 'affirmative action' or preferential hiring of women law professors in the 1990s showed a slight statistically significant 'over'-representation of women (and men of colour) in law school hiring in the period between 1986 and 1991, along with continued statistically significant underrepresentation of women of colour (Merritt and Reskin 1997: 299).

Nationally, leading female law professors have used their stature to speak against continuing gender discrimination in the legal academy, describing the multiple ways in which it occurs through mechanisms that are both overt and covert and operate at both macro and micro levels (Kay 1991; McGinley 2005; Resnick 2003; Rhode 2003; Levit 2001). After a long period of extreme underrepresentation (Kay 2002), more women are becoming law school deans, though these statistics may in part reflect the fact that, in increasingly hard financial times for US law schools, these leadership positions have become less attractive to men (ABA 2016).

Other studies document increasing segregation in the types of courses male and female US law professors teach, with women increasingly tending to teach subjects associated with femininely gendered topics - such as family law, anti-discrimination law, juvenile law, poverty law and social legislation - and men increasingly tending to teach 'higher' status subjects - including constitutional law, business law and some commercial law subjects (Kornhauser 2005: 330-31). Observers often conclude, correctly, that these findings reflect continuing structural discrimination against female law faculty. This report on the experiences of Lytle, Mussey, Gillett and Armstrong raises some interpretive cautions, however. Undoubtedly, Kornhauser and others' results reflect continuing discrimination, but an additional variable may be that, as women gain more secure footholds in legal academia, they may have more freedom to teach subjects they find important despite traditional, male-dominated assumptions about the status hierarchy of various legal fields. In other words, it is not 
necessarily an unmitigated negative sign that women teach subjects such as family law and social legislation, just as it was not necessarily a sign of subordination that these were the subjects of Barbara Armstrong's teaching and scholarly focus. ${ }^{2}$

Finally, and most importantly, contemporary empirical studies of US legal academia clearly document an over-concentration of women in 'helping' roles in law school teaching, including non-tenure eligible jobs in legal writing and clinical programmes (Merritt 2000 249-50; Levit 2001: 778-79). In contrast, tenure and tenure-track professors are assigned 'authoritative' roles, such as teaching large exam courses that deliver little individualised attention to students. These roles remain traditionally and historically gendered male even as more women assume them. Thus, a comparison of types of law teachers, rather than simply gender ratios within the law professors at the top of the status hierarchy, shows strong continuing genderbased stratification, much as, in the early twentieth century, women law teachers were concentrated in lectureships or other non-tenure positions.

In many US law schools legal writing and clinical jobs carry less job security, prestige and salary. Here again, the narrative arising out of the data must be presented with some nuance. In some schools (including my own), clinical law professors have fought for and won parity with so-called 'stand up' teachers, pushing as well for change in the discourse concerning the value of different types of law school teaching. Legal writing professors are currently engaged in similar campaigns. These initiatives calling for revaluing types of law school teaching are infused with gender-influenced values and the gendered historical tradition from which those values arise. It is therefore important to appreciate both the continued subordination of women in law teaching as measured against certain indices of status and prestige, and the embedded gendered assumptions on which those 'prestige' indices are built.

Finally, there is abundant evidence of gender disparities in the salaries paid to law teachers, even in equivalent jobs. No one has yet penetrated US law schools' penchant for secrecy to conduct a multi-institutional public study of race and gender disparities in law professor salaries, but some institutions have disclosed such information. At least one law school faced a discrimination lawsuit as a result (Hart 2014). A leading gender discrimination scholar has pointed out the potentially large liability risk US law schools face for such employment discrimination claims (McGinley 2005).

\section{CONCLUSION}

In conclusion, early 'firsts' - including Lytle, Mussey, Gillett, Armstrong and others have left women law professors in the US a legacy that combines great progress with glaring continuing problems, especially in occupational stratification and pay disparities. This complex mixed picture shows all signs of persisting into the future, requiring continued vigilance, protest and reform.

\footnotetext{
${ }^{2}$ Findings on female faculty members' differential course assignments correspond with empirical findings that female US law students are more likely to go into public interest career specialties than male law students (Dinovitzer and Hagan 2014). While it would be over-simplistic to characterise these findings of gender-differentiated career paths as simply the outcome of 'choice' (Rhode 2003), my report similarly identifies political and law reform motives for the accomplishments of female US law professor 'firsts'.
} 
Yet the historical study of women's entry into legal academia in the US raises important analytical complexities, which caution against over-simplistic conclusions even about the present day. I have argued for the importance of examining the relationship between women's professional lives as legal academics and other aspects of their identity. Barbara Armstrong, for example, had hybrid life commitments; this fact, I have argued, is key to understanding her success. Her commitments to activism and social policy propelled her into legal academia. Once there, an academic position allowed her to take risks in championing progressive policy change. Armstrong's involvement in creating social policy helps explain how she managed the feat of becoming the first tenure-track female professor at an AALS-member law school. A cause bigger than her own self-advancement pushed her forward, and provided her the grist for the scholarship that dazzled her academic evaluators. To understand Armstrong as a law professor 'first', one must also understand her role as the underrecognised designer of national policy that mitigated the harshness of old age in the US by providing for social security. Had Armstrong been male, her notoriety might have been far greater; yet possible interactions between gender and perspective arguably contributed to her creativity too.

In terms of overall lessons, the US example involved historical circumstances that created tensions, including ambiguity about what law professors should be, which allowed for change. There was not only one path for women's advancement in legal academia, and this may remain true today.

\section{REFERENCES}

'A Colored Woman Lawyer' Salt Lake Herald (15 September 1897a).

Ali, Omar J (2008) 'Lytle, Lutie A' in Henry Louis Gates and Evelyn Brooks Higginbotham (eds), African American National Biography, 2nd edn, Vol 7 (New York, Oxford University Press).

American Bar Association (ABA) Section of Legal Education and Admissions to the Bar (2016) Law School Faculty and Staff by Ethnicity and Gender in 2013: www.americanbar.org/ groups/legal_education/resources/statistics.html.

Armstrong, Barbara (1932) Ensuring the Essentials: Minimum Wage Plus Social Insurance - A Living Wage Program (New York, The Macmillan Company).

_ (1936) 'The Federal Social Security Act and Its Constitutional Aspects' 24 California Law Review 247.

- (1953) California Family Law: Persons and Domestic Relations, the Community Property System, vols 1 \& 2 (San Francisco, CA, Bancroft-Whitney Co).

- (1965) Interviews with Peter Corning (Oral History Research Office of Columbia University).

Burton, Jean (1947) Katharine Felton and Her Social Work in San Francisco (Stanford, CA, Stanford University Press).

Carle, Susan D (2013) Defining the Struggle: National Organizing for Racial Justice, 1880-1915 (New York, Oxford University Press).

Clark, Mary L (1998) 'The Founding of the Washington College of Law: The First Law School Established by Women for Women' 47 American University Law Review 613.

'Colored Girl Lawyer' Vermont Phoenix (26 November 1897b). 
Dauber, Michelle Landis (2013) The Sympathetic State: Disaster Relief and the Origins of the American Welfare State (Chicago, IL, The University of Chicago Press).

Diepenbrock, David A (1994) 'Florence Wycoff, Helen Hosmer, and San Francisco's Liberal Network in the 1930s' 3(2) Ex Post Facto: The History Journal 47.

Dinovitzer, Ronit and Hagan, John (2014) 'Hierarchical Structure and Gender Dissimilarity in American Legal Labor Markets' 92 Social Forces 929.

Downey, Kirstin (2009) The Woman Behind the New Deal (New York, Random House).

Gordon, Linda (ed) (1989) Women the State and Welfare (Madison, WI, University of Wisconsin Press).

'First Colored Woman Lawyer' Iowa State Bystander (24 September 1897).

Harno, Albert J (1953) Legal Education in the United States (San Francisco, CA, Bancroft-Whitney Co).

Hart, Melissa (2014) 'Missing the Forest for the Trees: Gender Pay Discrimination in Academia' 91 Denver University Law Review 873.

Henderson, Taja-Nia Y (2017) “I Shall Talk to My Own People”: The Intersectional Life and Times of Lutie A Lytle’ 102 Iowa Law Review 1983.

Kansas Historical Society (2004) Lutie Lytle, October 2004: www.kshs.org/kansaspedia/ lutie-lytle/12136.

Kay, Herma Hill (1991) 'The Future of Women Law Professors' 77 Iowa Law Review 5.

- (2002) 'Women Law School Deans: A Different Breed, or Just One of the Boys' 14 Yale Journal of Law and Feminism 219.

Kimball, Bruce A (2009) The Inception of Modern Professional Education, CC Langdell, 1826-1906 (Chapel Hill, NC, North Carolina Press).

Kornhauser, Marjorie E (2005) 'Rooms of their Own: An Empirical Study of Occupational Segregation by Gender among Law Professors' 73 UMKC Law Review 293.

Levit, Nancy (2001) 'Keeping Feminism in its Place: Sex Segregation and the Domestication of Female Academics' 49 University of Kansas Law Review 775.

Lindgren, James (2016) 'Measuring Diversity: Law Faculties in 1997 and 2013' 39 Harvard Journal of Law \& Public Policy 89.

Lopez, Eduard A (1987) 'Constitutional Background to the Social Security Act of 1935' 50(1) Social Security Bulletin 5.

'Lutie Lytle, "Miss Lutie Lytle Speaks"' Topeka Daily Capital (15 September 1897) (quoted in Smith, 2000: 11-12).

McGinley, Ann C (2005) 'Discrimination in Our Midst: Law Schools' Potential Liability for Employment Practices' 14 UCLA Women's Law Journal 1.

_ (2009) 'Reproducing Gender on Law School Faculties' 3 Brigham Young University Law Review 99.

McLeod, Jacqueline A (2005) 'Legal Profession' in Darlene Clark Hine (ed), Black Women in America, 2nd edn (Oxford, African American Studies Center): www.oxfordaasc.com.

Merritt, Deborah Jones (2000) 'Are Women Stuck on the Academic Ladder? An Empirical Perspective' 10 UCLA Women's Law Journal 241.

Merritt, Deborah Jones and Reskin, Barbara F (1997) 'Sex, Race, and Credentials: The Truth about Affirmative Action in Law Faculty Hiring' 97 Columbia Law Review 199.

Muncy, Robyn (1991) Creating a Female Dominion in American Reform, 1890-1935 (New York, Oxford University Press).

Powell, Thomas Reed (1967) Vagaries and Varieties in Constitutional Interpretation (New York, AMS Press, Inc).

Resnick, Judith (2003) 'A Continuous Body: Ongoing Conversations about Women and Legal Education' 53 Journal of Legal Education 564. 


\section{Susan D Carle}

Rhode, Deborah L (2003) 'Midcourse Corrections: Women in Legal Education' 53 Journal of Legal Education 475.

- (1897b) 'Miss Lytle. First Colored Woman Lawyer' Salt Lake Herald (27 September 1897). St Paul Globe, No title (20 September 1897).

Sheppard, Steve (ed) (1999) The History of Legal Education in the United States Vol 1 (Pasadena, CA, Salem Press).

Smith, J Clay Jr (1993) Emancipation: The Making of the Black Lawyer, 1844-1944 (Philadelphia, PA, University of Pennsylvania Press).

(2000) Rebels in Law: Voices in the History of Black Women Lawyers (Ann Arbor, MI, University of Michigan Press).

Smith, Jason Scott (2014) A Concise History of the New Deal (New York, Cambridge University Press).

Stevens, Robert (1983) Law School: Legal Education in America from the 1850s to the 1980s (Chapel Hill, NC, University of North Carolina Press).

Traynor, Roger J et al (1977) 'Barbara Nachtrieb Armstrong - In Memoriam’ 65 California Law Review 920.

White, G Edward (2016) Law in American History, Vol II (New York, Oxford University Press). 